\title{
RISK OF PROBABLE INCIDENTS DURING RAILWAYS TRANSPORT ${ }^{1}$
}

DATA PRZESŁANIA: 10.12.2015 | DATA AKCEPTACJI: 12.12.2015 | JEL CODE: L92

\section{Assoc. Prof. RNDr. PhD Sarka Hoskova-Mayerova}

University of Defence, Faculty of Military Technology

Department of Mathematics and Physics

Kounicova 65, Brno, Czech Republic

email: sarka.mayerova@unob.cz

\section{Ing. Olga Becherova}

University of Defence, Faculty of Military Leadership

Department of Emergency Management

Kounicova 65, Brno, Czech Republic

email: filarskaolga@yahoo.com

In recent years, transport has become more important, especially in the context of globalization. In this article authors discuss the prediction of possible emergency events connected with the railways transportation. Firstly, there is given an overview of current situation in the EU. Secondly, it is pointed out to relevant legislation and briefly described particular emergency events. Afterwards there is a summary of the important emergency events that occurred in people and goods transport on railways recently in the Czech Republic. Finally, the causes of those are evaluated. The analysis of the current state of the rail transportation of hazard materials set the objectives and limitations of the written work.

KEYWORDS incident, railways, transport of dangerous substances, the risks involved in transporting hazardous substances, risk segments

1 The first author has been supported within the project for "Development of basic and applied research developed in the long term by the departments of theoretical and applied bases FMT (Project code: "VYZKUMFVT (DZRO K-217)" ) supported by the Ministry of Defence of the Czech Republic. 


\section{INTRODUCTION}

In recent years, transport has become more important, especially in the context of globalization. Basic activity within shipping is transportation, which ensures the physical movement of the goods (or persons) from the starting point to the destination. Another important area of transport is material handling, which may also be defined as the physical movement of material, however with the aim of further action (transportation, storage, etc.). A specific area of material transport is transportation of hazardous material. This area requires more emphasis on prevention and transportation safety. It is evident that properly secured loads prevent injuries to people, damage to vehicles and property, and congestion due to lost cargo. Cargo that has not been properly secured might fall off, affect the balance of a vehicle and sometimes even tip it over and cause accidents.

Every day a great number of trains transport a large volume of products, including chemical substances. Accidents may represent a serious risk for the population and they often cause water, air and soil to become polluted. Due to the properties of some of the transported substances (such as chemical products, hydrocarbons and fertilizers), the high volume of traffic together with high density of population, the possibility of an accident occurring and having severe consequences should not be neglected. In fact, several surveys have indicated an increasing trend in the frequency of accidents in the transportation of hazardous materials (Oggero et al., 2006).

\section{TOOLS, METHODOLOGIES AND POLICY RELEVANCE IN THE EU CONTEXT}

As written in a special report of European Court of Auditors called "Rail freight transport in the EU: still not on the right track",

the transport sector is increasingly faced with several issues related to the rising of traffic demand such as congestion, energy consumption, noise, pollution, safety, etc. Due to its low external and environmental costs, railway can be considered (together with inland waterways and short-sea-shipping) as a key factor for the sustainable development of a more competitive and resource-efficient transport system (European Commission, White Paper, 2011).

In order to reinforce the role of rail in European transport, there is a strong need of addressing the efficiency of the system and customers' satisfaction through targeted actions, i.e. rising reliability and quality of service. This becomes particularly pressing as many parts of the existing railway infrastructures are reaching their maximum capacity thus shrinking their capability to provide users and customers a higher or even adequate level of service. Taking also into account that transport demand forecasts for 2030 clearly show a marked increase of rail activity across the whole of Europe, we aim to address the issue of rail congestion in the context of relevant policy questions:

Is the actual rail infrastructure really able to absorb forecasted traffic, without significant impacts on punctuality of the system?

Would the already planned interventions on the European railway infrastructure guarantee an adequate available capacity and consequently adequate reliability and level of service? To which extent would the coveted competition in an open railway market be influenced by capacity scarcity, mainly during peak hours or along more profitable corridors?

An accurate estimation of capacity of the rail network can help answer these questions, leading policy makers to better decisions and helping to minimize costs for users. In this context 
this report explores the issue of capacity scarcity and sets this issue in the context of other relevant policy issues (track access charges, cost/benefit and accessibility measures, maintenance programmes, freight services' reliability, external, marginal congestion or scarcity cost for rail, impacts of climate changes, etc.), providing a methodological review of capacity and punctuality assessment procedures. To better explore the real applicability and the time and/or data constraints of each methodology, the study reports some practical applications to the European railway network. Finally, in the last section the report discusses the topic from a modelling perspective, as the quantitative estimation of railway capacity constraints is a key issue in order to provide better support to transport policies at EU level (European..., 2014).

\section{RAIL FREIGHT TRANSPORT IN THE EU}

As mentioned in Special Report (Special Report, 2016),

the promotion of more efficient and sustainable methods of transport, in particular rail freight, has been a key part of EU policy for the last 25 years. The EU budget contributed some 28 billion euros to funding rail projects between 2007 and 2013. This report assesses whether the EU has been effective in enhancing rail freight transport and whether EU rail freight transport performance has improved in terms of modal share and volume transported since 2000. We found that, overall, rail freight transport performance remains unsatisfactory, while the position of road transport has grown further.

The finding of the report: "The performance of rail freight transport in the EU remains unsatisfactory overall and the road remains the leading mode of freight transport in the EU" needs quick and effective action of all involved.

Notwithstanding the efforts made by the Commission since the 2001 White Paper, the performance of the transport of goods by rail in the EU remains unsatisfactory overall. The volume of freight transported annually by rail remained relatively stable between 2000 and 2012 (around 400 billion tonne kilometres). During the same period, though, the volume of freight transported by road increased (from 1,522 to 1,693 billion tonne kilometres).

This has resulted in the market share of rail freight as a proportion of total inland freight transport declining slightly. It decreased from $19.7 \%$ in 2000 to $17.8 \%$ in 2013 , whereas the proportion of goods transported by road increased slightly from $73.7 \%$ to $75.4 \%$ during the same period. This trend puts at risk the achievement of the target set in the Commission's 2011 White Paper of shifting as much as $30 \%$ of road freight being transported over distances greater than $300 \mathrm{~km}$ to other modes of transport such as rail or waterborne transport by 2030 (Special Report, 2016).

Naturally, the danger of accidents on railways is connected with such an effort. To create the rail transport as safe as possible it is important to know what kind of danger one can expect. The occurrence of a traffic accident represents the highest risk while transporting dangerous substances on railway. Leakage of a dangerous substance causes high danger for health and lives of people, environment and property. The next part of the paper deals with the accidents on railways while transporting dangerous items and type of risks connected with it. 


\section{ACCIDENT RATE ON RAILWAYS WHILE TRANSPORTING DANGEROUS ITEMS}

\section{ČD Cargo, a.s.}

ČD Cargo, a.s. was found as a subsidiary company of České dráhy, a.s. on 01.12.07 by investing the part of $\check{C} D$, a.s. freight transport. $\check{C} D$ Cargo, a.s. is the largest Czech railway transport provider. It offers the transport of extensive range of goods, from raw materials to products with high added value, transport of containers, exceptional deliveries, lease of railway wagons, spur-line, and other transport services. The annual volume of the transport of goods ranks it amongst five largest railway transport providers within the EU member states. It provides the services to the customers in approximately a thousand of locations in the Czech Republic, and by means of subsidiaries in the whole of Europe. The operation of freight wagons in ČD Cargo, a.s. is provided by over 900 engines - both electrical and motor operated. It provides the domestic and international transport according to various requirements of our clients. The strategic goal of ČD Cargo, a.s.is to maintain the leading market position of the freight railway transport in the Czech Republic and the Central European Region, and at the same time remain the efficient customer focused company (ČD CARGO, 2016).

As it was mentioned before, the occurrence of traffic accident represents the highest risk while transporting dangerous substances on railway.

\section{EMERGENCY EVENTS WHILE TRANSPORTING DANGEROUS SUBSTANCES ON RAILWAY IN CZECH REPUBLIC}

Following data were given to us by $\check{C} \mathrm{D}$ Cargo just for the research purposes. As it is obvious from table 1, in 2010-2014 in the Czech Republic there were in total 1,557 emergency events (EE) while transporting dangerous substances on railway.

Table 1. Number of accidents while transporting dangerous substances on railway

\begin{tabular}{|l|c|c|c|c|}
\hline \multirow{2}{*}{ Year } & \multicolumn{4}{|c|}{ Number of EE on railway } \\
\cline { 2 - 5 } & A & B & C & Total \\
\hline 2010 & $3(2)$ & $62(5)$ & $327(80)$ & $392(87)$ \\
\hline 2011 & $5(2)$ & $72(3)$ & $264(71)$ & $341(76)$ \\
\hline 2012 & $1(0)$ & $50(6)$ & $263(83)$ & $314(89)$ \\
\hline 2013 & $1(1)$ & $45(5)$ & $218(72)$ & $264(78)$ \\
\hline 2014 & $3(1)$ & $51(6)$ & $192(74)$ & $216(81)$ \\
\hline Total & $13(6)$ & $280(25)$ & $1,264(380)$ & $1,557(411)$ \\
\hline
\end{tabular}

Source: done by author (Internal materials).

Based on their magnitude, EEs are divided into 3 categories:

- A - serious accidents,

- B - danger,

- $\mathrm{C}$ - accidents.

A serious accident (A) in railway transport means a collision or derailment of railway carriages which occurred in relation with railway transport, resulting in death, or harm of at least 5 people or damage of great extent (more than 5,000,000 Czech korunas). An accident (C) in railway 
transport is a situation which occurred in relation with railway transport resulting in death, harm or significant damage (more than 500,000 Czech korunas). Other EEs are considered to be danger (B) (Act. 1994).

From the point of view of seriousness, there were in total $0.83 \%$ in the category of serious accidents, $17.9 \%$ in the category of danger, and $81.18 \%$ in the category of accidents.

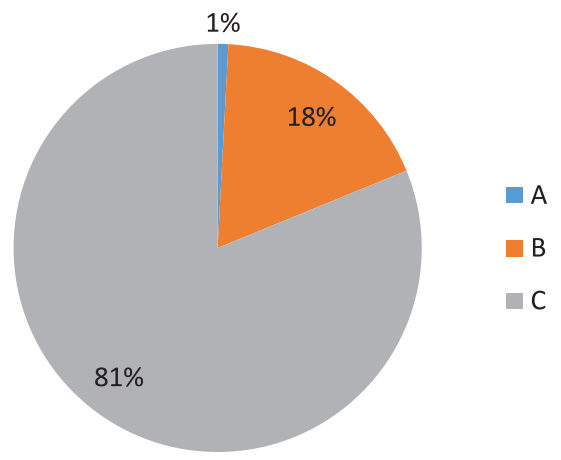

Figure 1. Distribution of EE with respect to the category of seriousness

Source: done by author (Internal materials).

According to the numbers given in brackets in table 1, we can state that to a certain extent employees affect EEs. Even if EEs caused by employees are not frequent, it is necessary to prevent these accidents and eliminate them.

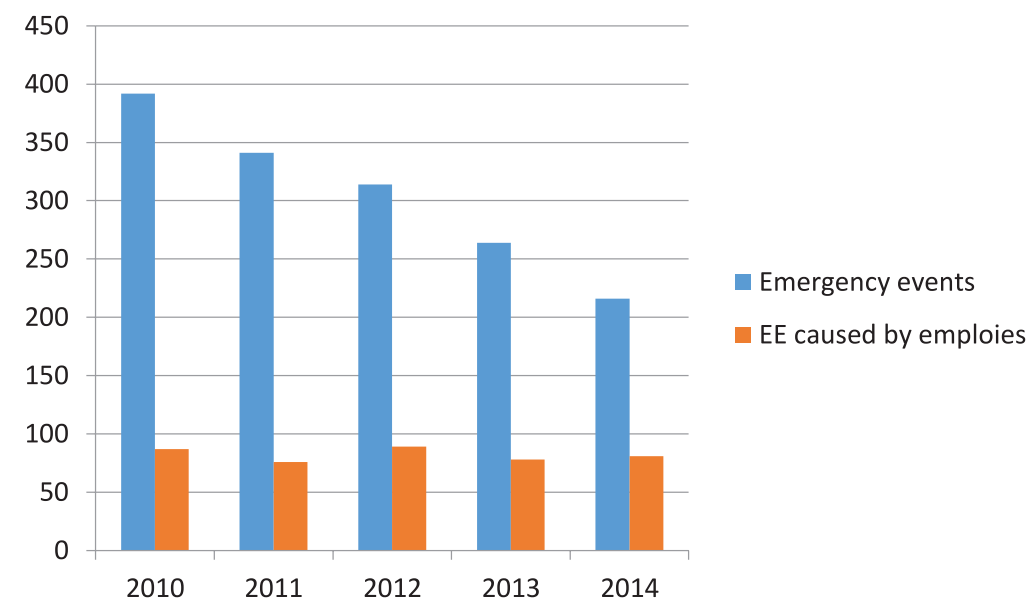

Figure 2. Distribution of accidents as a function of time Source: done by author (Internal materials). 
Railway accidents where an employee or a train unit is (partly) at fault are caused by:

- insufficient professional training and maintenance of professional knowledge and drivers skills,

- wilful failure to abide regulations and legislation,

- drivers' lack of attention,

- low quality trainings,

- technical condition (security systems).

Railway accidents where an employee or a train unit is not at fault:

- terrorist attack,

- climate and industrial conditions (flood, strong wind, landslide),

- unauthorized access on rails (suicides),

- imperfection of tracks (bridge collapse).

\section{RISKS OF RAILWAY TRANSPORT OF DANGEROUS SUBSTANCES}

\section{MANIFESTATION OF ACCIDENTS}

Accidents connected with leakage or explosion (fire) of chemical substances during transporting are specific. Therefore, it is necessary to study these cases in order to be able to foresee their occurrence. Most often we meet fires followed by explosions and leakage of toxic gases or vapors. E.g. when two carriages collide there are risks involved that can cause - simply said -3 situations (European..., 2014 \& Internal materials).

Table 2. Basic accidents and their manifestations

\begin{tabular}{|l|l|l|}
\hline \multicolumn{1}{|c|}{ Accident } & \multicolumn{1}{|c|}{ Manifestation } & \multicolumn{1}{c|}{ Notes on accidents } \\
\hline Fire & heat radiation & $\begin{array}{l}\text { usually only time and spatial restrictions, restricted } \\
\text { involvement of persons, ignition of materials or destruction } \\
\text { of materials, damage of environmental elements, usually } \\
\text { extensive material damage }\end{array}$ \\
\hline Explosion & $\begin{array}{l}\text { pressure wave scattering } \\
\text { of debris fragments } \\
\text { including shards of glass }\end{array}$ & $\begin{array}{l}\text { quick course of events, restricted involvement or } \\
\text { danger of persons or animals, involvement of buildings, } \\
\text { constructions, technologies, synergic and cumulative effect } \\
\text { on surrounding objects, material damage }\end{array}$ \\
\hline Toxic substance leakage & toxicity & $\begin{array}{l}\text { significant involvement and/or danger of persons, animals, } \\
\text { extensive damage of environmental elements, material } \\
\text { damage is usually insignificant }\end{array}$ \\
\hline
\end{tabular}

Source: Melkes, Mika, 2015, p. 121.

\section{FAULT TREE ANALYSIS METHOD}

Fault Tree Analysis is a deductive technique that focuses on one particular accident or a failure of the system and highlights the method for determining the causes of such events. Fault tree is a graphical model that shows the different combinations of equipment failures and human errors that can result in serious system failures (i.e. Peak event). FTA strength is in its ability to identify the essential combination of equipment failures and human errors that can lead to an 
accident. The logical failure model system uses Boolean logic gates (e.g. AND, OR)(European..., 2014).

The procedure of this method may be as follows:

- classify the initial events and their possible causes,

- draw the tree disorders which nodes form the crossroads of "AND" and "OR",

- identify and describe the processes of failure of an individual component, identify the individual probabilities,

- establish the likelihood of conjunction and disjunction of the individual probabilities (Special Report, 2016).

\section{APPLICATION FOR FTA TRANSPORT OF DANGEROUS GOODS ON RAILWAYS}

Fault tree analysis (FTA) is a top down, deductive failure analysis in which an undesired state of a system is analyzed using Boolean logic to combine a series of lower-level events. This analysis method is mainly used in the fields of safety engineering and reliability engineering to understand how systems can fail, to identify the best ways to reduce risk or to determine (or get a feeling for) event rates of a safety accident or a particular system level (functional) failure.

In the following picture (fig. 3) the Fault Tree of a particular EE - Derailment is shown.

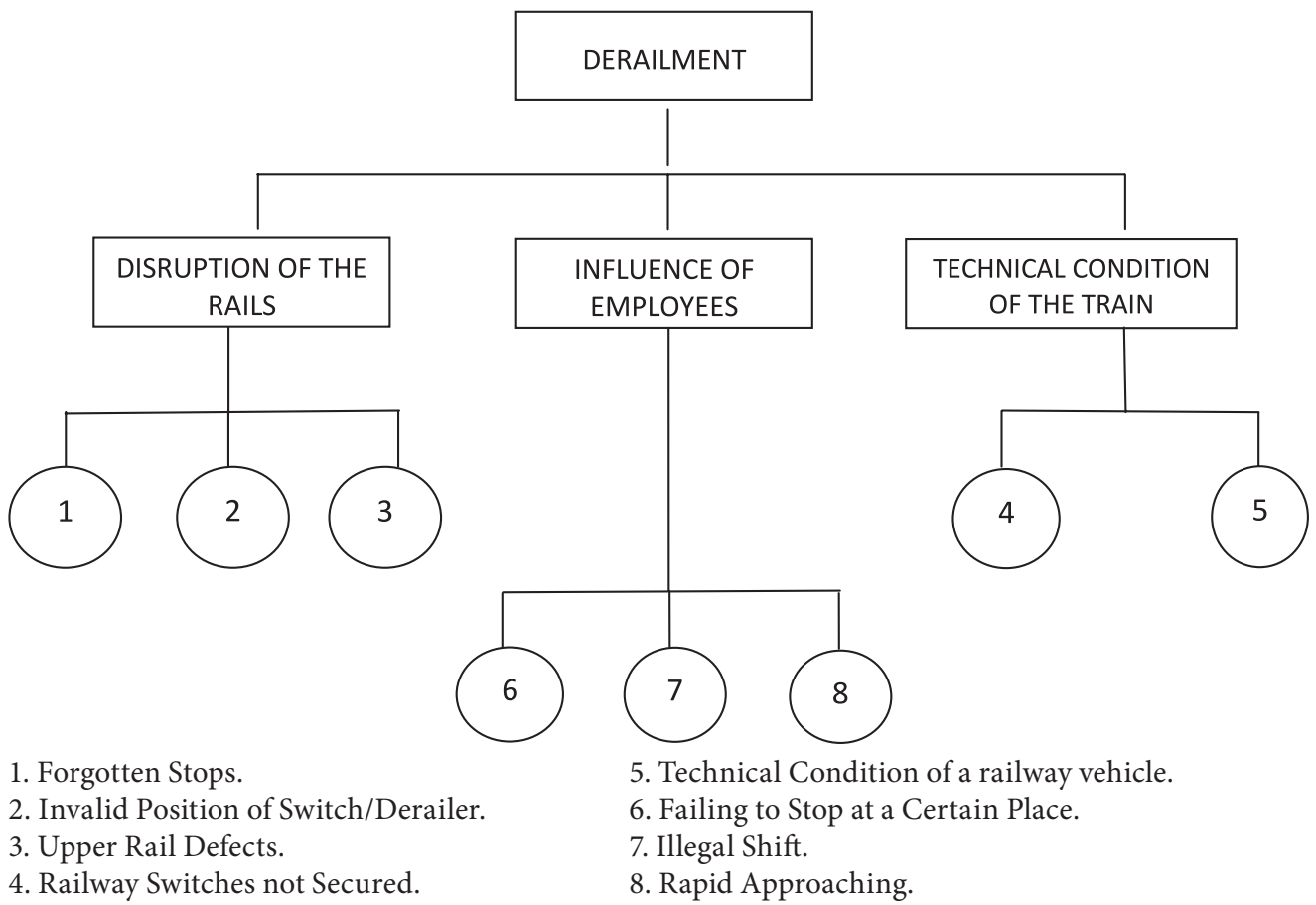

Figure 3. Fault Tree - Derailment

Source: done by author. 
This method can be used for example to determine the likelihood of an accident from the circumstances which might affect its creation. Using internal materials provided by ČD Cargo (Czech Railways Cargo) where determined following risk categories (Internal materials):

- derailment,

- collision,

- collision with the car at the rail crossing,

- collision with the person,

- fire,

- torn train,

- failure to respect signal device,

- damage to the railway tracks or train set,

- other.

\section{CONCLUSION}

Transport is one of the most complex processes when handling dangerous substances (DS). Every day a great number of trains transport a large volume of products, including chemical substances. Accidents may represent a serious risk for the population and they often cause water, air and soil to become polluted. The possibility of an accident occurring during the transport and having severe consequences should not be neglected. Due to its complexity the entire process has to be precisely organized and regulated. By the FTA method it is possible to determine the likelihood of an accident from the circumstances which might affect its creation.

\section{REFERENCES}

Act no. 266/1994 Coll. on railway, (in Czech: Zákon č. 266/1994 Sb., o dráhách).

Czech Railwais Cargo. (2016). ČD Cargo, a.s. Available at: https://www.cdcargo.cz/o-spolecnosti.

European Best Practices Guidelines on Cargo Securing for Road Transport: available online from: http:// eca.europa.eu/en/cargo-securing-for-road-transport-pbMI0614080/?CatalogCategoryID $=\mathrm{h} 4 \mathrm{QKAB}$ strmIAAAEjv5EY4e5L, 2014.

European Commission. (2011). White Paper. Available online at: https://ec.europa.eu/transport/themes/ strategies/2011_white_paper_en.

Internal materials of ČD Cargo (Czech Railwais Cargo).

Melkes, V., Mika, O. (2005). Prevence závažných průmyslových havárií. Brno, p. 121.

Oggero, A., Darbra, R.M., Munoz, M., Planas, E. and J., Casal, A. (2006). Survey of accidents occurring during the transport of hazardous substances by road and rail. J Hazard Mater.

Special Report. (2016). Rail freight transport in the EU: still not on the right track. Available online at: www. eca.europa.eu/Lists/.../SR16.../SR_RAIL_FREIGHT_EN.pdf.

Šovčíková, L. (2005). Závažné priemyselné havárie a ich následky, Žilina, p. 117. 


\section{Ryzyko prawdopodobnych zdarzeń w czasie transportu kolejowego}

STRESZCZENIE W ostatnich latach, szczególnie w kontekście globalizacji, rola transportu wzrasta. W artykule przedstawiono potencjalne sytuacje kryzysowe związane z transportem kolejowym. Na początku przedstawiono przegląd aktualnej sytuacji w Unii Europejskiej, następnie przedstawiono aktualne przepisy związane $\mathrm{z}$ ruchem kolejowym i opisano różne rodzaje zagrożeń. W końcowej części artykułu przedstawiono zdarzenia, które miały miejsce w ostatnich latach w Republice Czeskiej, oraz oceniono ich przyczyny.

SŁOWA KLUCZOWE wypadek, kolej, transport substancji niebezpiecznych, ryzyko związane z transportem niebezpiecznych substancji, segmenty ryzyka

Translated by Sarka Hoskova-Mayerova 